\title{
Application of ampelographic parameters to differentiate native Vitis vinifera $\mathrm{L}$. cultivars
}

\author{
El Oualkadi A*, Hajjaj B*
}

\author{
*INRA- Regional Agricultural Research Center of Tangier, Morocco \\ Corresponding author. E-mail: ai.oualkadi@gmail.com
}

\begin{abstract}
This study was conducted in three vegetation successive periods $(2015,2016)$ to determine ampelographic characteristics of the 39 grapevine accessions prospected in the Northwestern of Morocco by ampelographic criteria using OIV descriptors. The data were processed by multivariate statistical procedures. The integration of the obtained data with ampelographic data would be very important for the accurate identification of the Moroccan cultivars and can become a significant tool for the certification of quality grapevine produced in specific region.
\end{abstract}

Keywords-Ampelography, Vitis vinifera, Morocco, OIV descriptors.

\section{INTRODUCTION}

The viticulture domain has always received a significant interest and grapes are extensively used worldwide for fruit and wine production. [1] Estimated the existence of about 14,000 cultivars, with numerous synonyms and occasional use of the same or similar names for genetically different cultivars. In the last decades it has become imperative to handle the large germplasm of grapevine as well, and to properly identify the different cultivars. Traditionally, morphological and agronomical characteristics have been the main criteria for differentiating grapevine cultivars. Ampelography is the first step in grapevine selection, in establishing the relationship within and among grape cultivars and in solving different classification problems [2]. In grapevine collections an average of $5-10 \%$ of cultivars are misnamed, and even in commercial viticulture misnaming and confusions related to synonyms and homonyms do exist [3].The morphological descriptors may be easy to examine and therefore they are useful for the laboratory and field research work [4]. The morphometric characterization of Vitis varieties is carried out by the measurement of parameters in leaves, grapes and separated grapes. The measurement eliminates subjective evaluation of data. Systems to directly digitize phylometric parameters from leaves have been developed [5], [6].

Grapevine varieties have been characterized for identification purposes by ampelographic characters [7], [8], [9]. Study of plant morphology, mainly leaves, buds, and grape morphology (also called ampelography) it is the last means of detecting vine cultivars [10]. This method is still used for identification [11], [12], [13], particularly during the collection of data plants in situ.
In Morocco, the grapevine as well as the olive tree, the fig tree and the cereals are cultures well adapted to the natural climatic conditions of our country located at the end of the western Mediterranean. Before, the native grape varieties occupied areas whose extent or relative importance could not be assessed, mainly mountain vineyards [14]. However, during the last century, several factors have led to a progressive extinction for many local grape varieties and consequently to their genetic erosion. Currently, these varieties have become rare, little known, not inventoried, unexplored and threatened with extinction. Little study in Maghreb was carried to describe the cultivars of grapevine [14], [15], [16], [17].

As the identification of grapevine varieties by the use of classical ampelographic methods (morphological and morphometric characters) are sometimes afflicted by mis interpretations due to environmental influence [18], the integration of our data with ampelographic data would be of great importance to unambiguously identify the existing Moroccan cultivars and could also be used for legal protection of cultivars.

Our goal in this study was to complete the characterization of Moroccan grapevine prospected in north-west region using the ampelographic descriptors to confirm the existing synonymies and possible relationships among the plant materials in order to preserve the maximum amount of genetic variability for breeding and commercial purposes.

\section{MATERIAL AND METHODS}

The plant materials consisted of samples from the prospection sites located at the north-west of the country, all of them were classified as minor or endangered 
varieties. The total number of accessions studied was 39 and 10 grapes for each tree (Table 1). Ampelographic characters were described using OIV descriptors [19]. Sampling was done at the time of fruiting. In each site surveyed and with the help of the farmers we collected for each variety named and recognized samples of fruits.

Principal Component Analysis (A.C.P) was done using SPSS Version 10 software.

Table 1. List of varieties studied

\begin{tabular}{llll}
\hline Feryal Khal1 & Aferyal Byad1 & Maticha Mferqa & Fekas khal \\
Feryal khal2 & Aferyal Byad2 & Maticha Mjemaa & Fekas Byad \\
Taferyalt kahla3 & Taferyalt Byad3 & Mouska & Fekas \\
Taferyalt Kahla4 & Taferyalt Byad4 & Mouska Bayda & Ineb Byad1 \\
Taferyalt Kahla5 & DiBI 1 & Mouska hamra1 & Ineb Byad2 \\
Taferyalt Kahla6 & Dibi 2 & Mouska hamra2 & Bezoul awda 1 \\
Taferyalt kahla7 & Echabel(Dibi) & Boukhanzir1 & Bezoul awda 2 \\
Taferyalt kahla8 & Dibani 1 & Boukanzir2 & Rjiyil Dib 1 \\
Sbiyae Bnat & Dibani 2 & Boukhanzir3 & Rjiyil Dib2 \\
Ineb Nhal & Sanso & Zbarjel & \\
\hline
\end{tabular}

\section{RESULTAT AND DISCUSSION}

\section{Average quantitative parameters of grapes}

For each tree, we measured the following variables: weight, length, width, peduncle length and number of wings for each grape (Table.1). The results obtained show important variations between the grapes of the different sampled varieties. For example, the Dibi 1 tree showed the highest average weight with $872 \mathrm{~g}$ per grape. On the other hand, the Maticha mferqa tree has on the contrary mounted grape with the lowest average weight with $71 \mathrm{~g}$. Also, the highest average grape length was observed in the Dibani 1 $(30 \mathrm{~cm})$ tree while the lowest average value was observed in the Taferyalt kahla $3(6.5 \mathrm{~cm})$ tree. Regarding the average width of the grapes, we noticed that the greatest average width of the grape was observed in the Ineb nhal tree $(16 \mathrm{~cm})$, while the lowest average value was observed in the Fakkas tree $(4 \mathrm{~cm})$. The average Length/Width ratio shows more or less homogeneous values in most grapes, the highest Length/Width ratio was observed in the Fekas tree (2.75), while the lowest Length/Width ratio was found in the Boukhanzir tree 3 (1.2). The average number of wings ranges from 29 in the Bezoul aouda tree 2 to 4 in the Taferyalt kahla 3 tree (Table 1).

Table.1. quantitative parameters of grapes

\begin{tabular}{|c|c|c|c|c|c|c|}
\hline Variety & $\begin{array}{l}\text { Total weight } \\
\text { (grape) }\end{array}$ & $\begin{array}{l}\text { Length } \\
(\mathrm{cm})\end{array}$ & $\begin{array}{l}\text { Width } \\
(\mathrm{cm})\end{array}$ & long/width & $\begin{array}{l}\text { Peduncle } \\
\text { length }\end{array}$ & Number of wings \\
\hline Feryal Khal1 & 435 & 28 & 17 & 1.64 & 3.5 & 18 \\
\hline Feryal khal2 & 129 & 17 & 10 & 1.70 & 3 & 16 \\
\hline Taferyalt kahla3 & 21 & 6.5 & 4.5 & 1.44 & 1.5 & 4 \\
\hline Taferyalt Kahla4 & 43 & 10.5 & 8 & 1.31 & 1.8 & 11 \\
\hline Taferyalt Kahla5 & 151 & 18 & 11 & 1.63 & 3.4 & 13 \\
\hline Taferyalt Kahla6 & 283 & 19 & 11.5 & 1.65 & 2 & 20 \\
\hline Taferyalt kahla7 & 333 & 21 & 11 & 1.90 & 2 & 21 \\
\hline Taferyalt kahla8 & 296 & 20 & 12 & 1.66 & 2 & 15 \\
\hline Aferyal Byad1 & 551 & 27 & 14 & 1.92 & 3.5 & 20 \\
\hline Aferyal Byad2 & 463 & 23.5 & 14 & 1.67 & 3.5 & 26 \\
\hline Taferyalt Byad3 & 74 & 17 & 11.5 & 1.47 & 4 & 12 \\
\hline taferyalt Byad4 & 17 & 8 & 5.5 & 1.45 & 4 & 5 \\
\hline DiBI 1 & 872 & 25 & 17 & 1.47 & 3.2 & 24 \\
\hline Dibi 2 & 400 & 30 & 17 & 1.76 & 4 & 27 \\
\hline Echabel(Dibi) & 348 & 24.5 & 13.5 & 1.81 & 5.5 & 17 \\
\hline Dibani 1 & 359 & 30 & 14 & 2.14 & 4.5 & 23 \\
\hline Dibani 2 & 139 & 15 & 11 & 1.36 & 2 & 16 \\
\hline Maticha Mferqa & 71 & 15.5 & 8.5 & 1.82 & 2.7 & 14 \\
\hline Maticha Mjemaa & 138 & 14.5 & 9 & 1.61 & 3.4 & 19 \\
\hline
\end{tabular}




\begin{tabular}{|c|c|c|c|c|c|c|}
\hline Mouska & 358 & 19 & 12 & 1.58 & 2.5 & 16 \\
\hline Mouska Bayda & 184 & 18.5 & 11 & 1.68 & 2.6 & 11 \\
\hline Mouska hamra1 & 20 & 15 & 7 & 2.14 & 2.2 & 16 \\
\hline Mouska hamra2 & 142 & 18.5 & 9 & 2.05 & 2.5 & 15 \\
\hline Ineb Nhal & 263 & 26 & 15.5 & 1.67 & 2.8 & 24 \\
\hline Fekas khal & 445 & 26 & 16 & 1.62 & 4.5 & 20 \\
\hline Fekas Byad & 222 & 14.5 & 7.5 & 1.93 & 3.2 & 23 \\
\hline Fekas & 10 & 11 & 4 & 2.75 & 2 & 10 \\
\hline Ineb Byad1 & 367 & 25 & 17 & 1.47 & 3.2 & 16 \\
\hline Ineb Byad2 & 157 & 20 & 8.5 & 2.35 & 2.3 & 14 \\
\hline Bezoul awda 1 & 43 & 14 & 5.5 & 2.54 & 1.5 & 14 \\
\hline Bezoul awda 2 & 239 & 15 & 8.5 & 1.76 & 3.2 & 29 \\
\hline Boukhanzir1 & 352 & 21 & 8.5 & 2.47 & 3.4 & 20 \\
\hline Boukanzir2 & 145 & 19 & 11 & 1.72 & 3.7 & 18 \\
\hline Boukhanzir3 & 163 & 13.5 & 11.2 & 1.20 & 2.2 & 9 \\
\hline Sbiyae Bnat & 93 & 10 & 6.5 & 1.53 & 3.5 & 10 \\
\hline Rjiyil Dib 1 & 277 & 20 & 12.5 & 1.6 & 2.2 & 16 \\
\hline Rjiyil Dib2 & 311 & 18.5 & 10 & 1.85 & 3.4 & 18 \\
\hline Zbarjel & 90 & 11.5 & 6 & 1.91 & 2.5 & 12 \\
\hline Sanso & 251.28 & 19.44 & 11.01 & 1.76 & 3.047 & 17.605 \\
\hline
\end{tabular}

Principal component analysis

We used the means of the quantitative parameters of the grapes to perform a principal component analysis. Table 2 shows the percentages of the variance associated with each axis.

Table 2: Variances associated with the axes of the ACP of the characters of the grape

\begin{tabular}{cccc}
\hline \multicolumn{4}{c}{ Total variance explained } \\
\hline component & Total & \% de la variance & \% cumulative \\
\hline 1 & 4.829 & 40.242 & 40.242 \\
2 & 1.944 & 16.198 & 56.440 \\
3 & 1.653 & 13.775 & 70.214 \\
4 & 1.033 & 8.605 & 78.820 \\
\hline
\end{tabular}

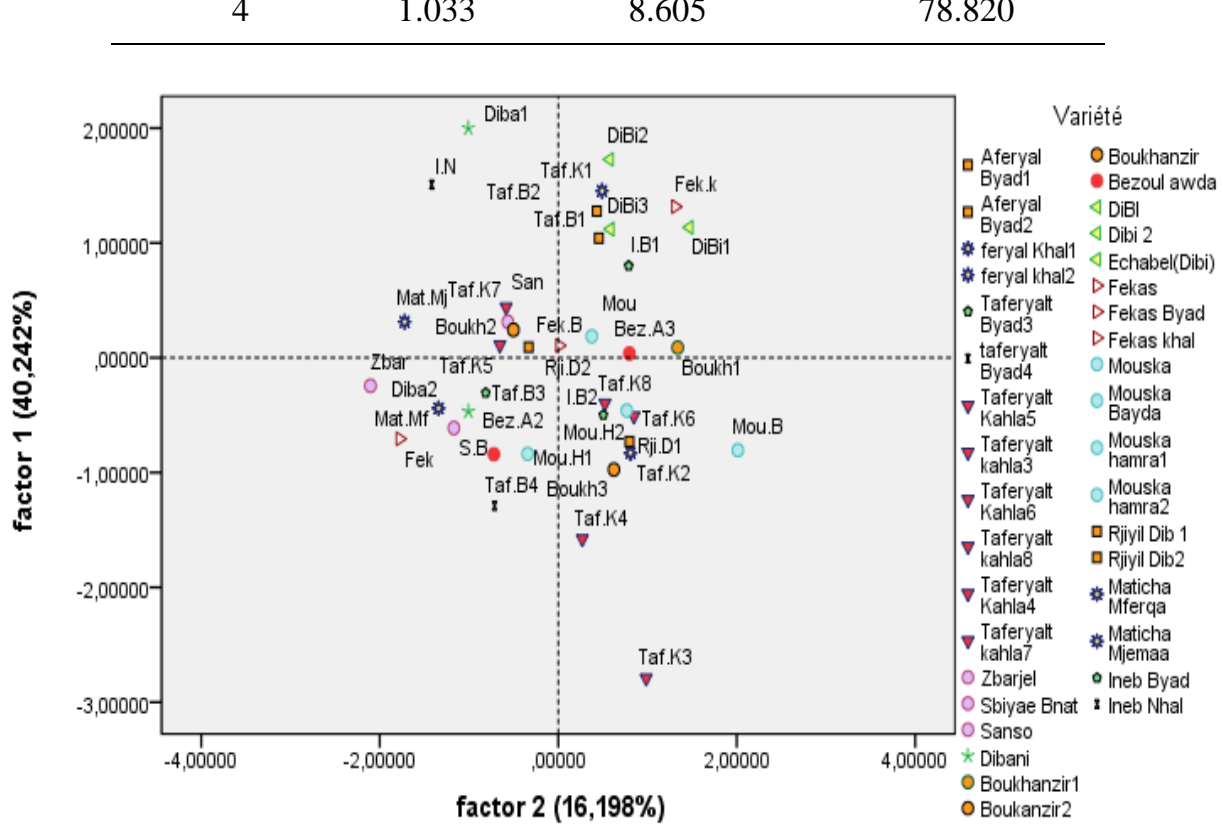

Fig 1. Projection in the plane $(1,2)$ of the principal component analysis 
From the result obtained in Figure 1 we see a compact structure of all trees, no structuring is visible. To better see the structure we eliminated the 12 trees of the "variety" Taferyalt and redo the analysis with only the other varieties. Figure 2 shows the result obtained.

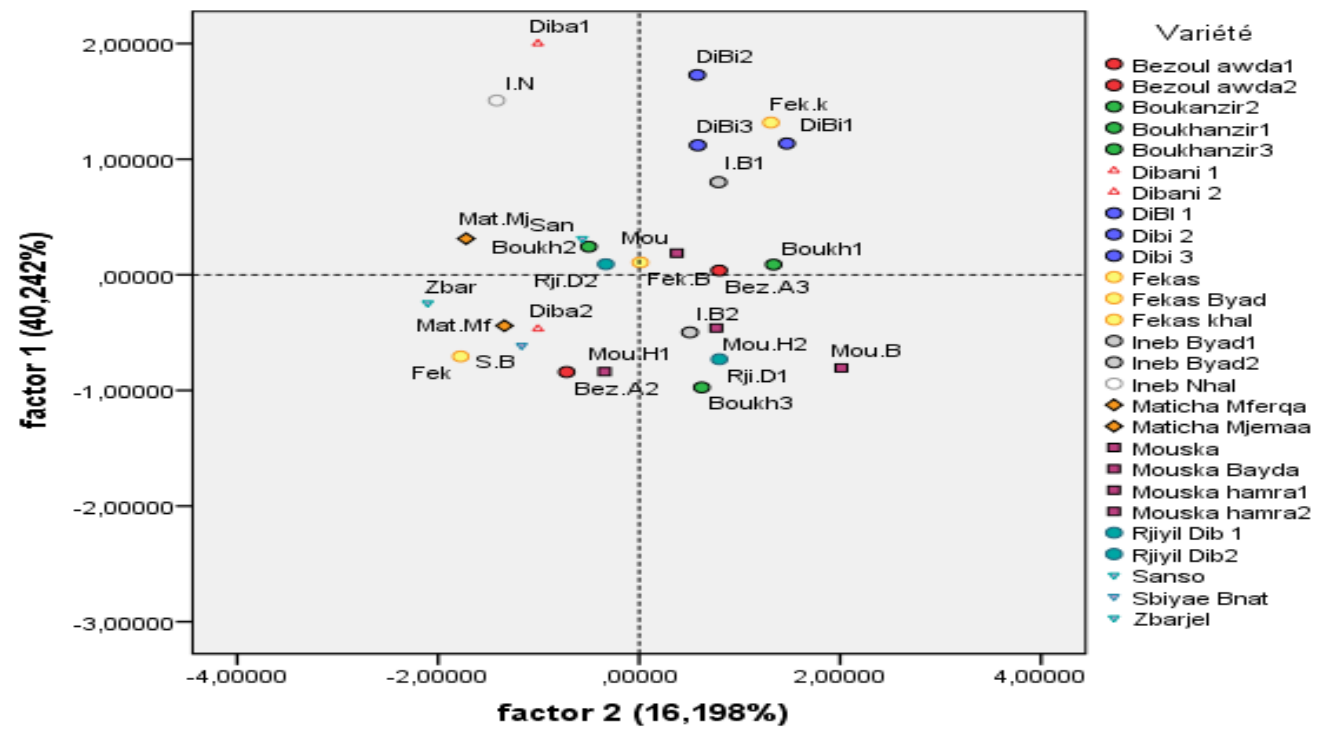

Fig. 2: Projection in the plan $(1,2)$ of the principal component analysis (without Taferyalt cultivar)

In axis 1 , the representation shows that the weight variables, the length, the width of the bays are well correlated in the positive direction. Grape parameters: weight, length, width, number of wings and length of peduncle are moderately correlated with axis 1 . In the negative sense, the length-on-cluster variable is well correlated with the axis 1. From the analysis of Figure 2, we notice a variability resulting from the remarkable dispersion of the feet studied at the plane formed by the two axes (1 and 2). Axis 1 encompassing 40.24\%, of the total information, is defined positively and mainly by the lengths, the widths, the weights and by the numbers of the wings. Therefore, axis 1 opposes the three feet of the variety Dibi, Fekas khal, and Ineb byad 1 in the positive side. As for axis 2, which represent $16.19 \%$ of information. It is negatively defined by the sugar content encompassing the feet Maticha mjamaa and mfera, Dibani, Rjiyil Dib (Figure 2). In axis 1, the representation shows that the weight variables, the length, the width of the bays are well correlated in the positive direction.

Therefore, none of these characters distinguish varieties between them, at least from data obtained from our sampling. Indeed, from the results of the factorial analysis (A.C.P) of the quantitative and semi-quantitative parameters of the grapes and berries we note an absence of a net structuring of the feet of the different varieties. And this, despite the discriminating power of the parameters used between different feet without reference to the variety. It is then thought that there is a problem in this study which resides in the number of insufficient feet sampled and the lack of repetitions within the same variety. The only variety that has a large number of feet is the variety Taferyalt with 12 feet. On the other hand, we must not forget the problem of synonymy and homonymy that prevents a good characterization of varieties. For this, molecular characterization is essential for good discrimination of varieties.

\section{CONCLUSION}

Morocco is a very rich country in terms of homonymous grape varieties which results from the old tradition of grape cultivation in north-west of country, which began in romain period. We are of the opinion that it is crucial to preserve this genetic potential by describing a reasonable nomenclature and determining the relationships among these varieties through DNA-based markers.

\section{REFERENCES}

[1] Alleweld, G., Spiegel-Roy, P., Reisch, B., (1990) Grapes (Vitis). In: Moore, I.N., Ballington, J.L. (Eds.), Genetic Resources of Temprate Fruit and Nut Crops. Acta Hortic. 290, 291-337.

[2] Martinez de Toda F. and Sancha J.C. (1997) Ampelographical characterisation of red Vitis vinifera L. cultivars preserved in Rioja. Bulletin de L'O.I.V. 793-794: 220-230.

[3] Dettweiler E., Jung A., Zyprian E. and Töpfer R. (2000) Grapevine cultivar Müller-Thurgau and its true to type descent. Vitis 39: 63-65.

[4] Schneider A. (1996) Grape variety identification by means of ampelographic and biometric descriptors. Riv. Vitic. Enol. 49: 11-16. 
[5] Alessandri S., Vignozzi N. and Vignini A.M. (1996) AmpeloCADs (Ampelographic Computer-Aided Digitizing system). An integrated system to digitize, file and process biometrical data from Vitis spp. leaves. Am. J. Enol. Vitic. 47: 257-267.

[6] Schneider A. and Zeppa G. (1988) Biometria in ampelografia. l'uso di una tavoletta grafica per effettuare rapidamente misure fil lometriche. Vignevini 15: 37-40.

[7] Clemente, S. de R (1807) Ensayo sobre las variedades de vid común que vegetan en Andalucia, Madrid.

[8] Viala, P. \& V. Vermorel (1905) Ampélographie. Imp. Masson et Cie, Paris.

[9] Galet, P., (1962) Cépages et vignobles de France. Tome III, Les cépages de cuve (2a partie). Imp. Le Paysan du Midi. Montpellier.

[10] Boursiquot JM, This P (1996) Les nouvelles techniques utilisées en ampélographie: Informatique et marquage. J Int Sci Vigne Vin Special issue: 12-23.

[11] Arrigo N. \& Arnold C (2007) Naturalised Vitis rootstocks in Europe and consequences to native wild grapevine. PlosOne 6, 521.

[12] Ortiz JM, Martin JP, Borrego J (2004) Molecular and morphological characterization of a Vitis gene bank for the establishment of a base collection. Genetic Resources and Crop Evolution 51: 403-409.

[13] Pavek DS, Lamboy WF et Garvey EJ (2003) Selecting in situ conservation sites for grape genetic resources in the USA. Genetics Ressources and Crop Evolution 50: 165173.

[14] Levadoux, L., Benabderrabou, A. and Douaouri, B (1971) Ampélographie Algérienne: Cépages de cuve et de table cultivés en Algérie (SNED: Alger, Algeria).

[15] Föex, G. (1891) Cours complet de viticulture (Georges Masson Libraire Éditeur: Paris, France).

[16] Isnard, H (1951) La vigne en Algérie. Etude geographique (Ophrys: Gap, France).

[17] Vidal, J.P (1951) La vigne au Maroc (Terre Marocaine: Casablanca, Morocco).

[18] Dettweiller, E., (1993) Evaluation of breeding characteristics in Vitis. Influence of climate on morphologic characteristics of grapevines. Vitis 32, 249252.

[19] O.I.V (2001) Le code des caractères descriptifs des variétés et espèces de Vitis. O. I. V. (Off. Int. Vigne Vin), Paris.

[20] O.I.V (2007) OIV Descriptor List for Grape Varieties and Vitis Species. O. I. V. (Off. Int. Vigne, Vin), Paris. 